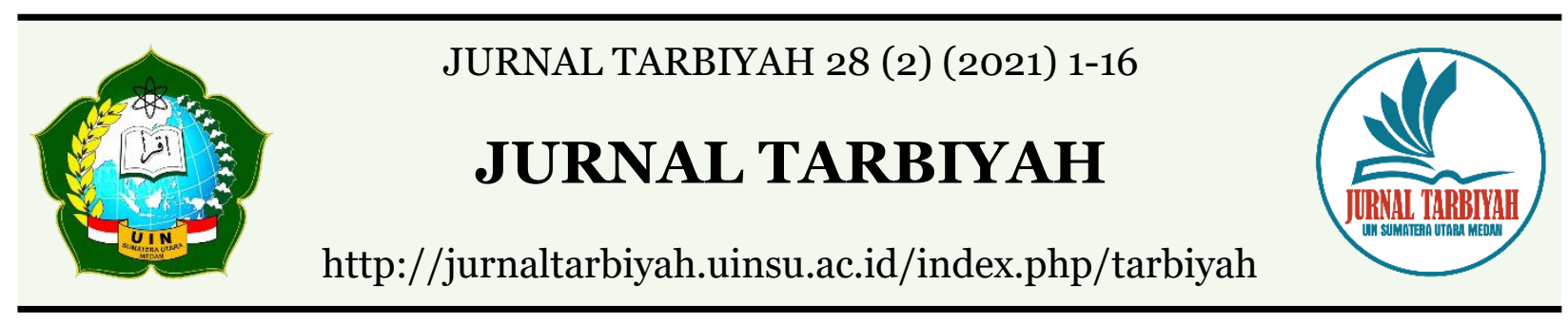

\title{
ANDROID-BASED FINANCIAL STATEMENT PRESENTATION MODEL
}

\author{
Pipit Putri Hariani MD', Indah Purnama Sari², Ismail Hanif Batubara ${ }^{3}$ \\ 1,2,3 Universitas Muhammadiyah Sumatera Utara, Medan, Indonesia \\ Email: ${ }^{1}$ pipitputri@umsu.ac.id, ${ }^{2}$ indahpurnama@umsu.ac.id, \\ 3 ismailhanif@umsu.ac.id
}

DOI : 10.30829/tar.v28i2.1107

Accepted: September 30th, 2021. Approved: December 28th, 2021. Published: December 30th, 2021

\begin{abstract}
This study aimed to help improve school financial management by diverting the recording of financial data manually and presenting it manually through an androidbased financial report presentation model to Muhammadiyah Vocational Schools in Medan City. The android-based financial report presentation model is carried out using descriptive qualitative methods based on the level of effectiveness and efficiency of using tools in the process of analyzing school financial data and supporting government efforts to reduce community activities outside the home, including education workers in order to reduce the spread of the COVID-19 virus as well as in efforts to reduce the spread of the COVID-19 virus in improving the quality of education through the use and use of technology. This research was carried out in several stages, starting from the stage of determining the problem, finding supporting data, and reaching the stage of data analysis; a model was obtained that was able to improve time efficiency in the presentation of financial statements when this model was applied to Muhammadiyah Vocational Schools in particular and other schools in Indonesia. Medan city and other regions, compared to the manual recording and presentation of financial statements.
\end{abstract}

Keywords: Android, Financial Report, Presentation 


\section{INTRODUCTION}

Money is one of the crucial things in life. Good money management at an institution requires generally accepted standard recording standards so that the financial statements prepared can describe the actual financial situation. Financial statements can be ascertained in every business activity in various sectors of life. The Education Sector is one institution that uses financial statements to measure financial performance. Many schools in Indonesia still use the manual recording in recording their financial activities. The process of processing school financial data, if done manually, will result in less effective (Habib \& $\mathrm{Al}$ Kindhi, 2018). In the current digital era, it is a challenge and necessary for every professional institution to have a good record of financial recording activities, taking advantage of technological advances with digital reports.

Private schools whose ownership is in private persons or foundations are increasing day by day, and many institutions are paying more attention to the progress of the world of education; one way is to establish schools by making contemporary learning innovations. Another important thing from the activities of advancing the school is to make the entire administrative system of the Institute run well and of good quality. One thing that needs to be considered is recording, reporting, and presenting financial statements. Inefficiency in one aspect will result in the difficulty of achieving maximum institutional performance because the management of educational finance needs to be adequately managed so that with existing funding, it can empower the school community in achieving educational goals. (Komariah, 2018).

Financial statements prepared manually have a high risk of recording errors because the accountant must understand it in compiling it manually with certainty the formulas and mechanisms of debit and credit. Naturally, if there is an error and error in manual recording one day, this will undoubtedly have a destructive impact on financial statements presented and will cause errors in decision making.

An excellent financial report is a financial report that accurately describes the business's financial position using a recording process according to applicable accounting standards. Financial statements contain information about assets, liabilities, equity, income, expenses, and distributions to interested parties as cash flows. The preparation of computerized and systematic financial statements is deemed appropriate for every recording of current financial statements. With computerized financial statements, recording activities become more practical and efficient and save time and avoid errors in addition and recording. Using excel for accounting is one of the practical ways in its 
effectiveness.

Excel for accounting is designed in such a way with algebraic formulas that can be used to facilitate us in the calculation process and avoid other errors. Financial transaction data that has been inputted into excel for accounting for further processing by using a database. Financial transactions can be stored neatly and well in the main computer with a database.

Financial statements stored on the main computer that are not integrated into any online system will remain there and can be used by interested parties with positions outside the school by sending the file via email, message, or even storing it on a flash disk. In the current era of rapid technological advances and accompanied by the COVID-19 pandemic, many parties have to move their work locations from work/school to home. Activities outside the house have become limited to avoid the spread of the Covid-19 virus; even the government has several times had to impose restrictions on community activities through PPKM. This reason is appropriate to use to develop a financial statement presentation system by utilizing Android owned by using a connected internet network. Officers preparing financial statements can still work on financial statements on the main computer at schools that have installed a network connection to the Android of the school party who has an interest in school financial statements. Those interested parties will be given a link, username, and password to access the school's financial statements anywhere, anytime, so there is no need to come to school or ask the financial officer to send the financial report file.

This research model will be carried out and developed at Muhammadiyah Vocational Schools spread across the city of Medan. Muhammadiyah Vocational School is one of the charities of the Muhammadiyah association in education. Muhammadiyah schools have an excellent opportunity to develop because Muhammadiyah also has a university in which one of the faculties is the teaching faculty, so that teaching methods and strategies can continually be developed and upgraded. Several other charities ranging from university-level to Al-Quran Education Park, Muhammadiyah focuses on the welfare of the people by establishing schools whose quality is consistently monitored to their financial performance so that Muhammadiyah schools can cover all levels of society. The performance and good focus of the Muhammadiyah association make academics seek to maximize their abilities and knowledge for their development and progress so that education and other fields can continue to develop following technological developments and the times. 
A picture of Muhammadiyah Vocational School (SMK) in Medan City is as follows:
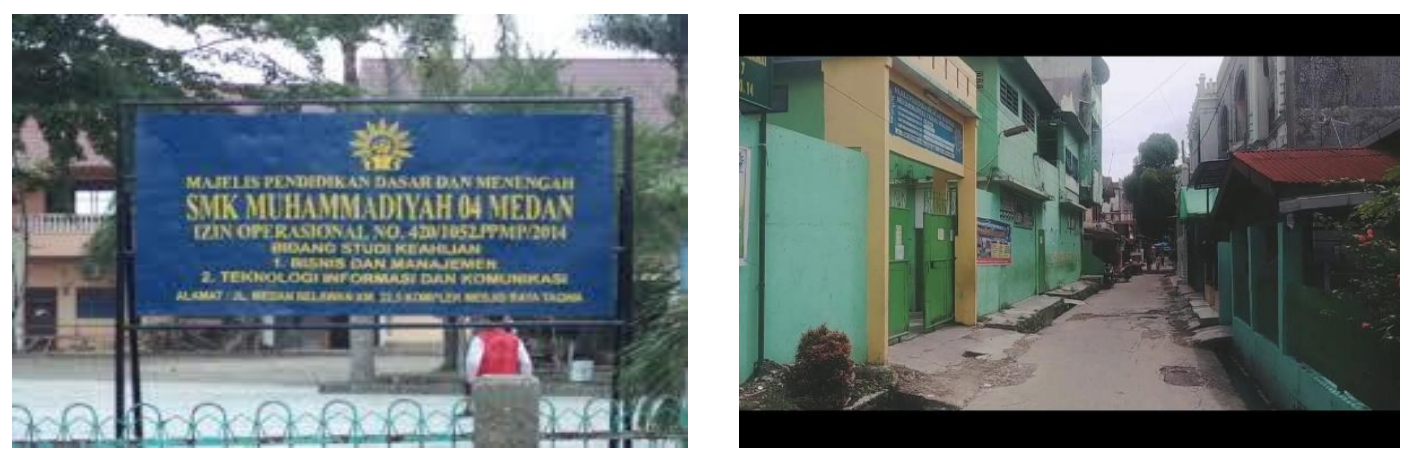

SMK Muhammadiyah 04 Medan Belawan SMK Muhammadiyah o6 Medan Area
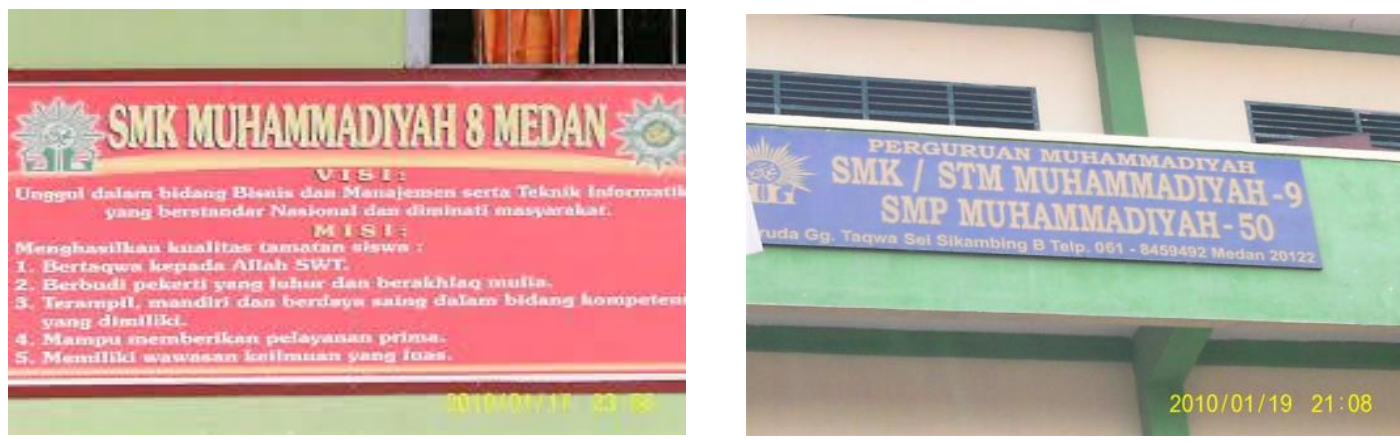

SMK Muhammadiyah o8 Medan Selayang SMK Muhammadiyah o9 Medan Sunggal

Pincture 1. SMK Muhammadiyah in Medan City

The picture above is a Muhammadiyah Vocational School building in Medan city; there are 4 Muhammadiyah vocational schools in Medan City. Recording computerized financial statements and presenting financial statements on a mobile basis is sought to improve school professionalism by getting used to using technology as a first step to developing the current capabilities of schools from other educational aspects so that they can survive amid the proliferation of schools in the city of Medan, and even be able to increase competitiveness in the community. By maximizing school activities that lead to the use of funds, decisions can be made through a reflection of appropriate financial performance because "to realize quality education, it is necessary to have comprehensive and professional management of existing resources in educational institutions. need to be managed properly in educational institutions is a financial problem." (Rahmah, 2016).

The background of this research on the presentation of android-based financial statements is based on a solution to simplify the process of presenting financial 
statements by financial stakeholders at SMK Muhammadiyah 04, SMK Muhammadiyah 06, SMK Muhammadiyah 08, and SMK Muhammadiyah 09 in the city of Medan so that it can support government policies to limit activities outside of the house to break the chain of the spread of the Covid-19 virus. Also, of course, to make SMK Muhammadiyah Medan a good school in its financial administration, with a link connected to the school's main computer, financial statements can be accessed anywhere and anytime to see the school's financial performance so that the right decisions can be reached regarding the use of funds to maximize school activities. The only parties who can access the link for presenting financial statements are given a username and password to log in. A trusted party entrusted with a username and password must have a sense of responsibility not to share it with unauthorized parties.

There are many obstacles experienced by stakeholders in reading school financial statements, especially if it is related to the significant distance between the readers of financial statements and the central computer that stores financial statements. Financial transactions must occur every day, both at school and in the business world, and even in daily life, so the data and records will change every day, even every hour and minute. It is our habit; if we need data, the file will be sent via WhatsApp chat, email, or other media. If we want to see the data progress every day, there are 30 (thirty) data files that fill the user's cellphone memory or laptop memory, even though we want to see only the latest data because the initial data already existed in the previous delivery. It is inefficient, so with an application for presenting financial statements that can be viewed via Android with the exact mechanism as using mobile banking, readers of school financial statements only need to check through the application without having to download files so that it is more practical, economical and technologically proficient.

Thus, this study will conduct an assessment of a model through existing literature which can later be developed in Muhammadiyah schools, especially at the vocational level, to assist the process of presenting integrated financial statements via Android with synchronization of the central computer network, to ensure school financial statements first. have been prepared according to accounting standards appropriately.

\section{LITERATURE REVIEW}

Business managers or organizations use financial statements as a controlling tool and a decision-making tool in financial matters. Financial statements prepared with correct standards can clearly and accurately describe the condition of the financial 
performance of a business/organization, be it a commercial or non-profit organization. The financial statements are commonly used as the information in assessing the potential changes of economic resources, which can be controlled in the future, and in predicting the production capacity of the resources owned (Orniati, 2009). Financial statements can also be interpreted as an output from the financial process carried out. (Kasmir (2015:10), 2015).

The school is a non-profit legal entity that is managed using school-based management. As a non-profit organization, school financial transactions can be arranged into financial statements that are different from the financial statements of commercial organizations/businesses. As a non-profit business entity, educational accounting uses a public sector accounting approach with financial statements in the form of (1) surplus/deficit reports, (2) cash flow reports, and (3) balance sheet reports. (Muchsini, 2015).

MySQL is a relational database management system. A relational database can store data in separate tables; this adds speed and flexibility.” (Sari, n.d.). MySQL software is an open-source application, and MySQL database server has a very fast, reliable, and easy to use performance and works with client-server architectures or embedded systems. Due to the open-source and popular factors, it is suitable for demonstrating the database replication process (Yuliansyah et al., 2014). Open means that anyone can download MySQL, both the original version of the program code and the binary version, and can be used for free, either for modification according to one's needs or as a computer application program. Therefore, the MySQL database software is suitable for making school financial statements integrated into the user's android system; in other words, MySQL can answer the challenge of limited funds in web and network management "lowcost high impact."

Information technology that is increasingly developing and sophisticated must be balanced according to needs. Due to the increasingly complex nature of the work being carried out, it is undeniable that every institution or other agency needs technology that can make it easier to provide information and speed up work. One of them can use computer technology, especially computers that use the internet. Financial statements prepared using computer technology with an accounting system that has been designed in it will produce financial statements that accurately describe financial performance. Good financial statements will result in effective financial decision-making. Accuracy and speed in preparing financial statements must be accompanied by timeliness in reporting 
and interpreting them so that decision-making related to business/organizational sustainability can run well. Using technology in recording and mobile in presenting reports will be able to project financial conditions in the future because "every school activity requires costs, this financial and financing component needs to be managed more effectively, efficiently, transparently and accountably, so that existing funds can support the achievement educational goals in schools, and following the demands of all existing stakeholders." (Utama \& Setiyani, 2014).

Timeliness is defined as the utilization of information by decision-makers before the information loses its capacity or ability to make decisions. Therefore, a piece of information is said to be irrelevant if it is not delivered on time (Srimindarti, 2008). In essence, financial statements provide information concerning the financial position, performance, and changes in the financial position of an enterprise that is useful to a wide range of users in making economic decisions. A financial report is helpful if the information presented can be presented accurately and on time (timeliness). Timeliness is one of the essential factors in presenting relevant information because, as stated in the basic framework for preparing the presentation of financial statements, timeliness is one of the qualitative characteristics that must be met. In principle, the faster the information provided, the more relevant the information will be for users of financial statements (Elviani, 2017).

During this covid-19 pandemic, it is necessary to innovate the presentation of remote financial statements that the authorized parties can use on these financial performances by connecting it through the school's central computer network, which is used as a tool to prepare school financial statements with the android of school financial stakeholders. So decision-making and financial accountability activities can be done from outside the school. School financial statements can be viewed for updated data by logging in via the link that has been designed and provided. It is almost the same as mobile banking; users can only view updated balances but cannot change or edit their contents. Editing authority remains on the school's parent computer. Meanwhile, the difference between the presentation of this android-based financial report and mobile banking is that this presentation system is not in a downloadable application but in the form of a link that can be accessed. It is done to avoid fees charged when using the application because it requires a more significant fee than using links that can be accessed. 
The following is the previous research that underlies the research conducted:

Tabel 1. Previous Research

\begin{tabular}{|c|c|c|}
\hline Author & Title & Results \\
\hline (Ria, 2018) & $\begin{array}{l}\text { Analysis of the Application of } \\
\text { Android-Based } \\
\text { Applications in the Financial } \\
\text { statements of UMKM Mekarsari } \\
\text { Depok }\end{array}$ & $\begin{array}{l}\text { Financial statements on } \\
\text { Android-based smartphones } \\
\text { are easy to use at any time. } \\
\text { Real-time information in this } \\
\text { system helps operations move } \\
\text { more effectively and } \\
\text { efficiently. }\end{array}$ \\
\hline $\begin{array}{l}\text { Sinarwati, } \\
\text { 2017) }\end{array}$ & $\begin{array}{l}\text { Mobile-Based Accounting } \\
\text { Information System for } U M K M\end{array}$ & $\begin{array}{l}\text { Developing a mobile-based } \\
\text { accounting information } \\
\text { system for UMKM can help } \\
\text { UMKM prepare financial } \\
\text { statements. }\end{array}$ \\
\hline $\begin{array}{l}\text { (Artawan et al., } \\
\text { 2020) }\end{array}$ & $\begin{array}{l}\text { Design and Build an Indonesian } \\
\text { Cooperative Electronic Application } \\
\text { (E-Koin) Mobile-Based }\end{array}$ & $\begin{array}{l}\text { Functionality test results show } \\
\text { that the system built can be } \\
\text { used to manipulate savings } \\
\text { and loan data and present } \\
\text { reports in the form of cash } \\
\text { flows, balance sheets, } \\
\text { remaining operating results, } \\
\text { and financial statements } \\
\text { through mobile-based } \\
\text { applications to members in } \\
\text { real-time. }\end{array}$ \\
\hline (Sari, 2015) & $\begin{array}{l}\text { Financial Report System Using } \\
\text { Mobile Phone, Php and Mysql }\end{array}$ & $\begin{array}{l}\text { Financial reporting and filing } \\
\text { of funds become more } \\
\text { manageable so that they can be } \\
\text { known directly by the } \\
\text { leadership in the company. }\end{array}$ \\
\hline
\end{tabular}




\begin{tabular}{|c|l|l|}
\hline \multicolumn{1}{|c|}{ Author } & \multicolumn{1}{|c|}{ Title } & \multicolumn{1}{|c|}{ Results } \\
\hline (Ja et al., 2020) & $\begin{array}{l}\text { Student Wallets at the Riyadlus } \\
\text { Sholihin Islamic Boarding School } \\
\text { Based on Mobile }\end{array}$ & $\begin{array}{l}\text { The student wallet system } \\
\text { designed using the Android } \\
\text { programming language can } \\
\text { provide information to the } \\
\text { guardians of students about } \\
\text { financial statements. }\end{array}$ \\
\end{tabular}

This research was a study that discussed and developed a model for presenting financial statements. Generally, financial statements are only in the form of presenting file-based or web-based financial statements, which will be developed into an Androidbased financial presentation model by utilizing the main computer as a tool for preparing financial statements to be accessed using a unique link username and password for its user.

All of the previous researchers who were used as references used mobile applications to prepare financial statements. In this study, the preparation of financial statements is still centered on the use of the school's main computer, but the presentation of financial statements or to view financial report data can be done using mobile. The development of this model is carried out for the efficiency of financial statement users in monitoring and evaluating financial performance through report data that can be accessed via mobile so that it can be viewed more efficiently anytime, anywhere, and under any conditions by utilizing the network. However, its reliability is maintained with a suitable recording mechanism that can only be done by school finance expert staff who have been given a user as an admin in a recording.

Recording can only be done on the main computer because if there is more than one bookkeeping user, it will cause chaos in the final data because all users can edit and manipulate the data. This presentation model can also be applied to other types of businesses outside of schools with almost the exact network liaison mechanism.

The mechanism is as follows: 

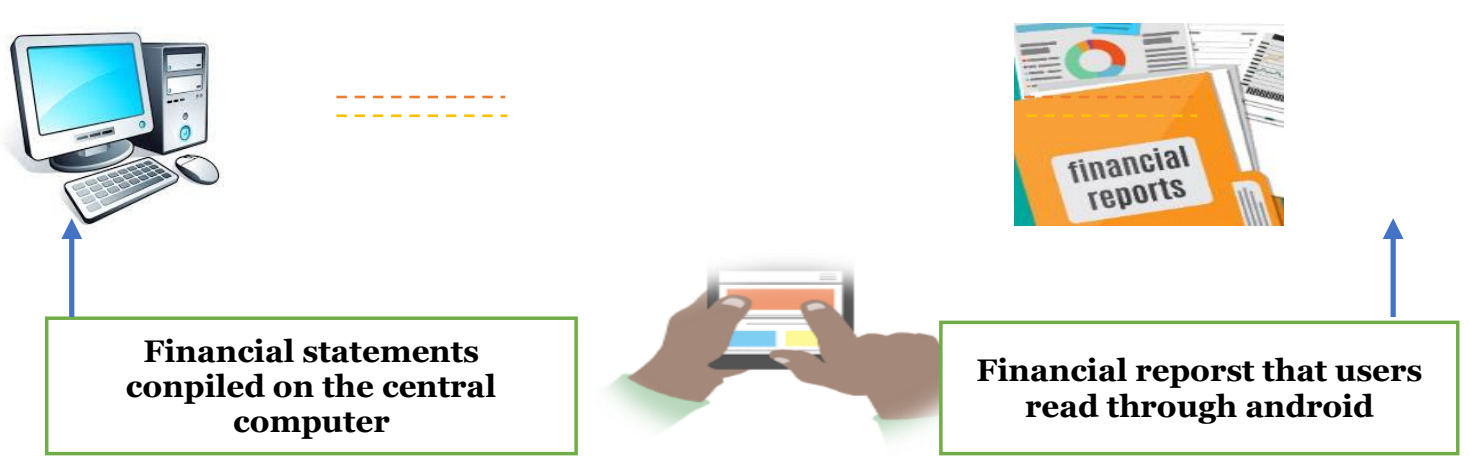

Picture 2. Mechanism of financial statements presentation

\section{RESEARCH METHOD}

This research is descriptive qualitative research that leads to model development research. Research research and development (R\&D) is a research method used to produce specific products and test the effectiveness of these products (Sugiyono, 2012: 407).

The stages of this research are:

1. Determining the Problem

This stage contains initial observation activities, collecting data and information related to the state of the school, and the process of preparing financial statements and presenting financial statements by the school to then know the relevant practical problems that occur;

2. Collection of Supporting Data

This stage is carried out to find and collect all supporting data related to the androidbased financial statement presentation model both from literature studies, library studies to facilitate researchers in developing models referring to the existing literature and data.

3. Data Analysis

Data analysis in this study was carried out through descriptive analysis, with the ultimate goal that the analysis leads to an android-based financial statement presentation model. 


\section{RESULTS}

\section{Manual Financial Report Presentation Process}

The process of preparing financial statements manually can be explained in the diagram as follows:
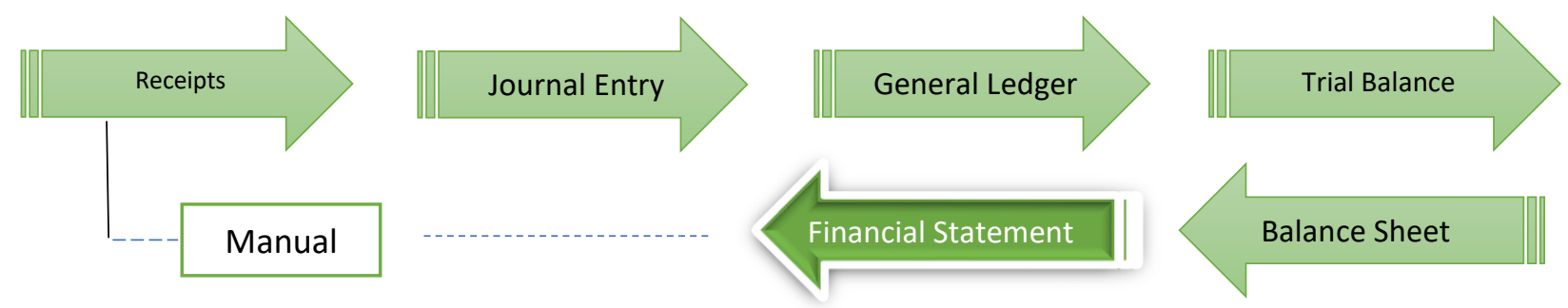

Picture 3. Flowchart of Manual Presentation System

Preparation of financial statements using accounting books will require several different books according to the accounting recording cycle so that financial data can be seen properly. The diagram above shows a manual accounting cycle with a bookrecording mechanism still widely used by schools today. Recording with the above mechanism will take quite a long time, and the correctness of the recording is at high risk of experiencing inaccuracies because the recording officer must adequately have the ability to memorize and understand the debit credit mechanism and formulas in accounting.

If the recording is done manually using an accounting book, the presentation of the financial statements can only be seen through the book containing the financial statements that have been prepared. When a book is damaged or lost, all data is ensured to be lost. In making financial decisions, parties with interest in the financial statements may need more than 1 (one) day to understand and analyze the contents of the report; this condition causes the manual to change hands and change places, the risk of damage is getting bigger, of course, this becomes an ineffective activity today where technology is high-speed and growing. 
If the recording cycle uses software assistance, for example, using excel for accounting, the cycle can be seen in the diagram as follows:

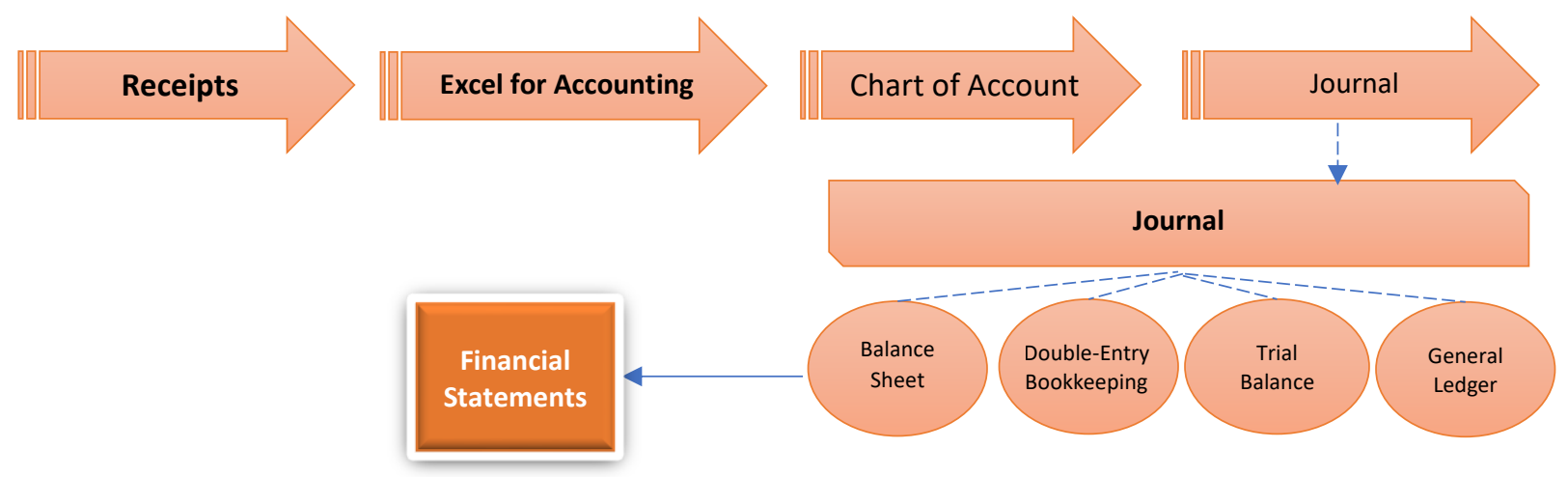

Picture 4. Flowchart of Excel for accounting-aided recording

The diagram above shows the flow of recording using excel for accounting. Data recording and input must be based on recorded financial transactions through valid transaction evidence. The data from the transaction evidence is then processed through EFA (excel for accounting) by first numbering or giving the account code for each transaction that occurs and is likely to occur in the future. The next step is to fill in the journal icon by writing the account code to automatically display the account name and typing the transaction value according to the data on the transaction receipt. In EFA, after the journal is filled in, the numbers in the general ledger, trial balance, AJP, and Worksheet will automatically be filled in, and the financial statements will also be automatically completed and can be viewed or printed.

Through a mechanism like this, the risk of errors in the recording will be smaller than the manual method. EFA, which is not integrated through a network of links into any application, the data can still only be seen in the presentation of the final result via excel. The parties interested in the data can request a copy/file submission via email or copy it to a flash disk. If there is a slight change in the data, the previous file that has been sent or copied is no longer valid, so that for the activity of presenting the updated report, you must request a resubmission. It, of course, uses a lot of storage memory on the file receiving device because there is a pile of received report files.

\section{Android-Based Financial Statement Presentation Model}

This study offers an android-based financial statement presentation model because almost all people, especially formal sector workers, use Android for daily 
communication tools and have certain internet network providers to connect their communication networks, so using Android to read and analyze financial reports can save time and power.

The following is a diagram of the Android-based financial statement presentation model:

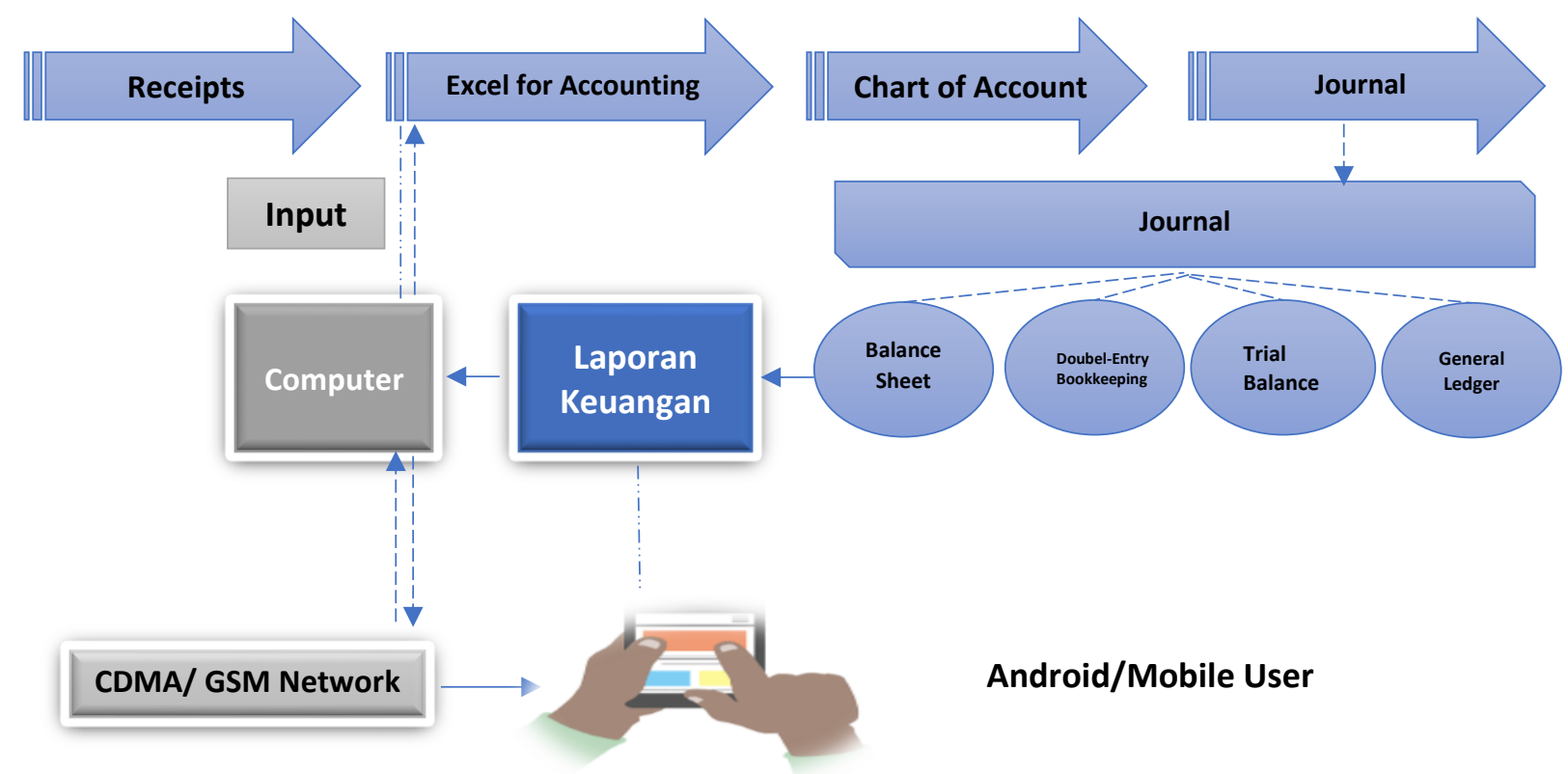

Picture 5. Flowchart of assisted-recording of excel for accounting and presentation of Android/mobile user reports.

The diagram above explains that the financial statement presentation model offered for Muhammadiyah schools can be accessed using the GSM/CDMA network owned by schools and users to easily access financial reports compiled on school computers using only Android. So that the activity of reading, checking, and analyzing financial reports becomes efficient.

Users can repeatedly view and open financial reports on Android without worrying about the cellphone memory being full because the data seen is not stored in the Android/mobile user's memory. Changes to data on the main computer automatically also change the data read by the user. Wouldn't this model make financial reports more practical to check data wherever the user is as long as they are connected to the network. This model supports the government's policy to do more activities at home but still be productive. 
This model was developed using Android-based technology with online data presentation. The use of remote technology is closely related to the use of the network for the access process. So, to view and read financial statements through this, Android must be connected via a network. For ease of use and to overcome the lack of good signal on the financial report reader network, this model will minimize the byte size of the presented financial report files so that in poor network conditions, financial statements can still be accessed.

\section{CONCLUSION}

From the study results, it can be seen that network technology plays an active role in facilitating human life, provided that it is used in the right conditions and at the right time. Through a network mechanism connected to a computer and a mobile user, there is an efficiency of time and energy to obtain school financial data only by using the GSM/CDMA network contained in the two devices.

The Android-based financial statement presentation model is strived to provide analysis of financial report data quickly, precisely, accurately, and practically to users so that decisions made by the school regarding the use of funds are better and faster. Appropriate financial decision-making can improve the quality of SMK Muhammadiyah Medan city schools through the design of productive activities that incidentally cannot be separated from the use of relatively large school funds. However, a computerized recording system and based on android/mobile users in presenting the report can provide a long-time efficiency for obtaining financial data and its analysis.

This research impacts school financial management by being able to streamline the management of funds to advance education by making appropriate decisions regarding school activities and all the resources in it that require funds to develop quality. Of course, this still has to be continued and developed in a better direction so that its use and application becomes wider in other sectors besides schools so that optimal results can be achieved.

\section{REFERENCES}

Artawan, I. M. A., Estiyanti, N. M., Lanang, I. G., Raditya, A., Sistem, J., Akutansi, I., \& Primakara, S. (2020). Rancang Bangun Aplikasi Elektronik Koperasi Indonesia ( EKoin Berbasis Mobile. Http://Ojs.StmikBanjarbaru.Ac.Id/Index.Php/Jutisi/Article/View/442/357 
Elviani, S. (2017). Faktor-Faktor Berpengaruh Bagi Ketepatan Waktu Pelaporan Keuangan Perusahaan Manufaktur Di Bursa Efek Indonesia. Jurnal Risert $\begin{array}{llll}\text { Akuntansi Multiparadigma (JRAM), } & \text { 4(3), }\end{array}$ File://C:/Users/HP/Downloads/327-876-1-SM.Pdf

Habib, A., \& Al Kindhi, B. (2018). Rancang Bangun Sistem Informasi Manajemen Keuangan Sekolah Design Of School Financial Management Information System. Intensif, 2(2), $2549-6824$ Https://Ojs.Unpkediri.Ac.Id/Index.Php/Intensif/Article/View/12139/963

Ja, W., Hasyim, F., \& Najiburrahman, M. F. (2020). Dompet Santri Di Pondok Pesantren Riyadlus Sholihin. 1(1), 35-42. File://C:/Users/HP/Downloads/1643-3672-1SM.Pdf

Kasmir (2015:10). (2015). Pengertian Laporan Keuangan. Harahap (2015:105),.

Komariah, N. (2018). Konsep Manajemen Keuangan Pendidikan. Http://Ejournal.Fiaiunisi.Ac.Id/Index.Php/Al-Afkar/Article/View/192

Muchsini, B. (2015). Prosiding Seminar Nasional Pendidikan Akuntansi Dan Keuangan. $\begin{array}{llll}\text { Membangun Daya Saing Banga, } & \text { 2, }\end{array}$ Https://Media.Neliti.Com/Media/Publications/171354-ID-Akuntansi-PendidikanSuatu-Pemikiran-Imp.Pdf

Orniati, Y. (2009). Laporan Keuangan Sebagai Alat Untuk Menilai Kinerja Keuangan. $\begin{array}{llll}\text { Jurnal Ekonomi } & \text { Bisnis, } & \text { 14(03), }\end{array}$ Https://D1wqtxts1xzle7.Cloudfront.Net/53039503/Yuli-

Orniati_4.Pdf?1494229932=\&Response-ContentDisposition=Inline\%3B+Filename\%3dlaporan_Keuangan_Sebagai_Alat_Untuk_ Meni.Pdf\&Expires=1613788263\&Signature=Xoj1p5asz9ftguezqbmty39j5lvco59rd3 ho85 Ltublfczzt6att

Rahmah, N. (2016). Prinsip-Prinsip Manajemen Keuangan Sekolah. Kelola: Journal of 
Pipit Putri Hariani MD et al./ JURNAL TARBIYAH 28 (2) (2021) 1-16

Islamic Education $\quad$ Management, $\quad$ 1(1), $\quad$ 73-77. Https://Doi.Org/10.24256/Kelola.V1i1.430

Ria, A. (2018). Analisis Penerapan Aplikasi Keuangan Berbasis Android. Sosio E-Kons, 1O(3), 207-219. Http://Journal.Lppmunindra.Ac.Id/Index.Php/Sosi_Ekons

Sari, M. (2015). Sistem Laporan Keuangan Dengan Menggunakan Mobile Phone, Php Dan Mysql. Https://Core.Ac.Uk/Download/Pdf/268601465.Pdf

Sinarwati, N. K. (2017). Sistem Informasi Akuntansi Berbasis Mobile Bagi Umkm. 4449. Https://Eproceeding.Undiksha.Ac.Id/Index.Php/Senari/Article/View/902/641

Srimindarti, C. (2008). Ketepatan Waktu Pelaporan Keuangan Oleh: Ceacilia Srimindarti Fakultas Ekonomi Universitas Stikubank Semarang. Jurnal Ilmiah Akuntansi Dan Bisnis, $\quad 7(1), \quad$ 14-21. Https://Www.Unisbank.Ac.Id/Ojs/Index.Php/Fe2/Article/View/204

Utama, D. A., \& Setiyani, R. (2014). Pengaruh Transparansi, Akuntabilitas, Dan Responsibilitas Pengelolaan Keuangan Sekolah Terhadap Kinerja Guru. Dinamika Pendidikan Unnes, 9(2), 100-114. Https://Doi.Org/10.15294/Dp.V9i2.4886

Yuliansyah, H., Studi, P., Informatika, T., \& Ahmad, U. (2014). Perancangan Replikasi Basis Data Mysql Dengan Mekanisme Pengamanan Menggunakan Ssl Encryption. $\begin{array}{llll}\text { Jurnal Informatika Ahmad Dahlan, } & \text { 8(1), }\end{array}$ Https://Doi.Org/10.12928/Jifo.V8i1.A2081 